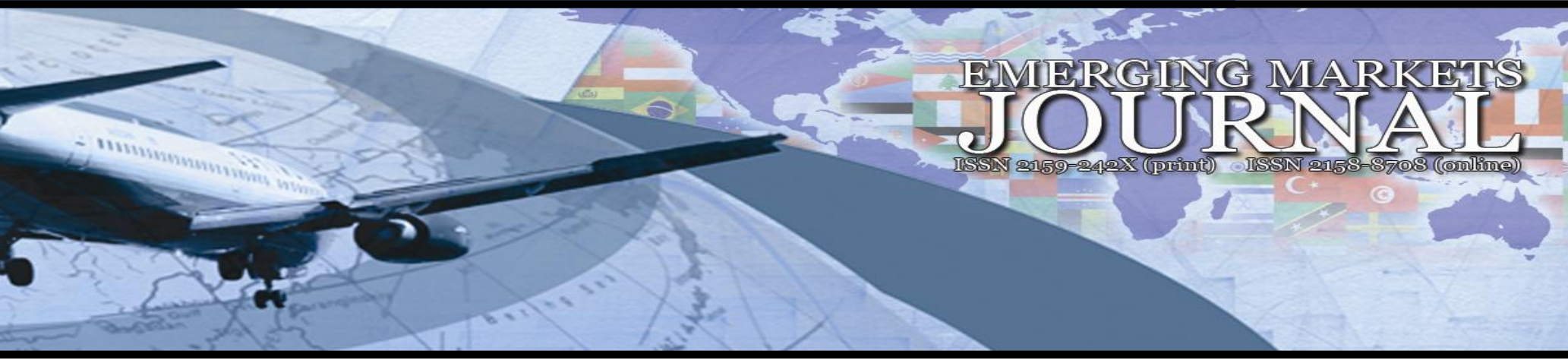

The Role of Participation Banking as Alternative Financing Channels to Substitute for Deposit Banks and its Growth in the Turkish Finance Market - Period: 2007-2015

\title{
Ferhat Sayım
}

Yalova University | f_sayim@hotmail.com

Volume 7 No 1 (2017) ｜ＩSSN 2158-8708 (online) ｜ＤOI 10.5195/emaj.2017.106 | http://emaj.pitt.edu |

\begin{abstract}
Financial systems and companies have become the most important reasons in the weakness of world economic system. The formation and development process of the financial structure also constitute the infrastructure of the world economic system. The path of the financial system and development has led to discuss with the financial crisis in 2008-2011. One of the solutions in order to reduce problems caused by the conventional banking system is alternative financing systems. In Turkey, the corporations based on profit share system are named participation banks. These banks which settle on different principles in the risk distribution of the portfolio acquired are analyzed more nowadays. Participation based banks are placed in practically every regulation related to banking terms and get their legal infrastructure more steady in the banking legislation of Turkey. This study is a continuation of a series related to the situation of participation banking in Turkey. On the other hand, the literature and the history of participation banking have been given less attention in this study. Literature information on methods in participation banks has been described in previous work of the series. Two analyzes were conducted in this study. One analysis is interpretive analysis that expresses the situation of applications of participation banking against banking risks. The other is an analysis of the figures of participation banks in Turkey as a continuation of the series. This study is a 2007-2015 part of research series. The study tries to explore the place and the importance of participation based banking with the various sub-headings, especially in Turkey. For this reason, we examine the comparative review 2007-2015 data of participation banks which are composed of Total Assets, Equity Net Profit, Collected Funds and Bank Loan Funds. Then we compare the total figures with deposit banks for the same period in Turkey.
\end{abstract}

Keywords: Bank, Finance Market, Participation Bank, Interest Free Banking, Alternative Banking System (cc) $\mathrm{BY}$

New articles in this journal are licensed under a Creative Commons Attribution 3.0 United States License.

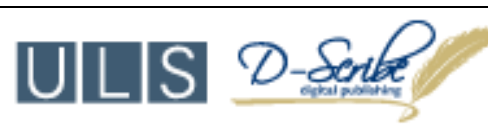

This journal is published by the University Library System of the University of Pittsburgh as part of its D-Scribe Digital Publishing Program, and is cosponsored by the University of Pittsburgh Press. 


\section{The Role of Participation} Banking as Alternative Financing Channels to Substitute for Deposit Banks and its Growth in the Turkish Finance Market - Period: 2007-2015

\section{Ferhat Sayım}

\section{1- Introduction}

Participation banks gather funds from saving owners, use them in industrial and trade sectors according to the interest free financing ethics and shares the profit or loss with saving owners. The word "participation" in their name expresses that this type of banking is based on the opinion of participation to profit and loss (The Participation Banks Association of TurkeyFAQ, 2010).

Banking methods of this system are generally called "Islamic Banking" in the international literature. These banking operations are methods such as various kinds of project partnership and others are based on prohibition of interest (Moles \&Tery, 1999, p. 304). As Islamic banking is part of the banking system of a country, its performance may affect the soundness and stability of the banking system (Abdul-Majid; 2008, p.4).

Moreover, for conventional banks with Islamic banking windows, the performance of these windows has certain influence on the performance of conventional banks (Abdul-Majid 2008, p.4). Islamic bank works as a trading concern and financial intermediary to perform interest-free activities purely according to principles of Sharia'h. It is a welfare organization that promotes business and trade activities by pooling the financial resources for the sake of profit and loss for mutual benefit (Ahmad, Humayoun, \& Hassan, 2010, p. 8).

The sources of funds for the banks are deposits, capital and equity. Deposits can be divided into transaction deposits or investment deposits which are respectively equivalent to current and fixed deposit accounts in conventional banking. Formerly, banks act as the safe-keeper which promises the nominal value of the transaction deposits, but does not guarantee returns on this liability and is known as wadiah. Later, depositors are not guaranteed nominal value nor paid with a fixed return. Instead, depositors are considered as shareholders, hence share profits or losses from the investment account with the bank. In addition, the proportion of the profits or the loss to be distributed is pre-determined and agreed by both parties (Abdul-Majid; 2008, p.4).

Participation or Islamic banks are not institutions specific to Turkey. All over the world, especially in Muslim countries, there are many financial institutions that operate according to a similar system. Even if it is known as "interest-free banking" or "Islamic banking", the system consisting of such institutions operating through profit and loss is perceived as a "special finance house" and later defined as "participation banking" under Turkish law.

MitGhamr Savings Bank established in 1963 in Egypt and the first modern experiment with Islamic banking can be traced to establishment of MitGhamr Savings Bank. The number and size of players operating in Islamic banking sector increased significantly along the past four decades. All over the world, there are applications of Islamic banking in more than 50 countries. There are countries where only Islamic banking is allowed such as Iran, Pakistan, and Sudan. On the other hand, there are some countries such as Bangladesh, Egypt, Indonesia, Jordan and Malaysia where both Islamic banking and conventional banking are allowed together. Also, Islamic banking can take place in non Islamic countries. (Chong \& Liu, 2009, s. 125-126).

The determination of the relative performance between Islamic banks and conventional banks will assist policy makers in devising a strategy to improve the performance of a banking system in a country and help managers in the conventional banks that choose having Islamic banking windows besides conventional banking to improve bank performance ( Abdul-Majid; 2008, p.4). 


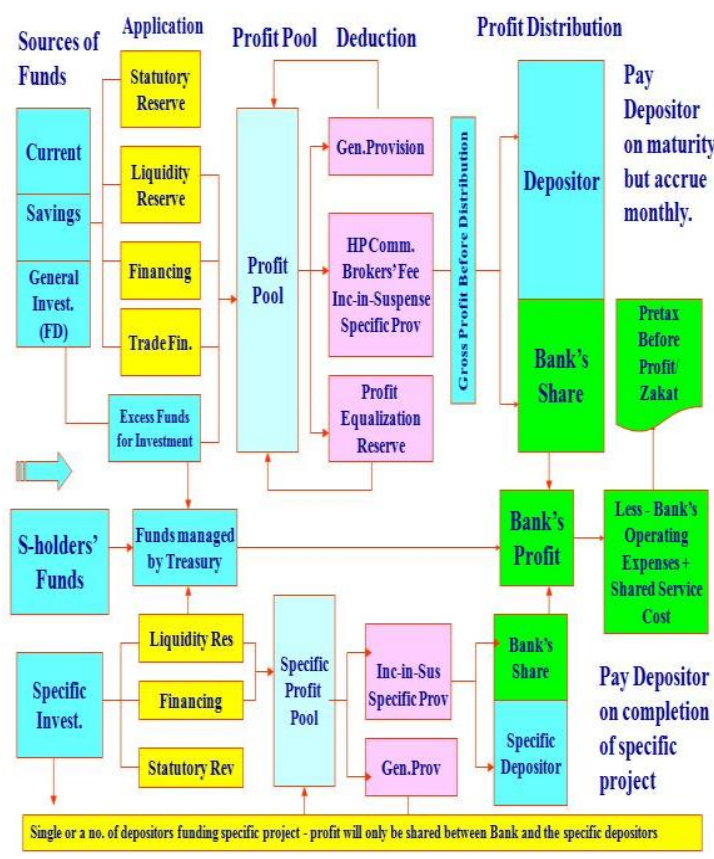

Figure 1. Application of Funds (Islamic)

Source: (Aminuddin, I.2010)

This study is a continuation of a series related to the situation of participation banking in Turkey. On the other hand, the literature and the history of participation banking have been given less attention in this study. Literature information on methods in participation banks has been described in previous work of the series. Two analyzes were conducted in this study. One analysis is interpretive analysis that expresses the situation of applications of participation banking against banking risks. The other is an analysis of the figures of participation banks in Turkey as a continuation of the series.

I. The Position of Participation Banks against General Risks Related to Banking

Below, the situation of participation banking applications against banking risks is interpreted. Interpreted risks are defined risks for banking. These can be listed as follows:

\section{Interest Rate Risk \\ 2. Exchange Rate Risk \\ 3. Security Price Risk \\ 4. $\quad$ Credit Risk \\ 5. Liquidity Risk \\ 6. Operational Risk \\ a) Interest Rate Risk}

According to the dividend-based system, it is uncertain that how much capital gains one can yield on the maturity. It is also possible that one can lose due to the credited projects. On the other hand, in the interest- based system, the committed amount is required to be paid to the capital owner on the maturity. The major difference between interest and dividend is that in the former, the capital gains are guaranteed on the maturity, whereas in the latter, the gains are closely connected to the efficiency of the projects.

The difference in those systems is able to minimize the interest risk for participation banks into a great extent. However, increasing deposit rates to manage funds of deposit banks facing interest rate risk in case of increasing interest rates may lead funds in deposit banks shifting from high-yield maturities into banks. Increasing participating fund customers that are insensitive to interest rates following rising integration of participation banks into the system may also lead to such initiatives. In this case, it is likely for participation banks to face with liquidity risk.

\section{b) Exchange Rate Risk}

Participation banks pay attention for not taking open or closed position that lead to exchange rate risk. However, nowadays, funding has been realized through various instruments, and the commodity-based transactions have become more and more related to participation banks. Similar to the exchange risk, there might be also a risk related to commodity-based funds when they are turned into cash and used in lieu of credit. Exchange rate risk is a risk that is supposed to be seriously considered by all the financial institutions.

\section{c) Security Price Risk}

Participation banks do not trade interest rate-based bonds and bills, but equities. The funds that are generated as basing upon the CMB regulations can be directed by managers that are authorized by participation banks. This risk would continue to be borne as long as the idle funds, apart from the ones that are already been established, have been used through security trade-off.

The rest of this part is related to the idiosyncratic risks, namely, credit risk, liquidity risk and operational risk.

\section{d) Credit Risk}

As participation banks do not offer cash credits, they are pulled away from taking credit risks based upon fictive transactions. However, like others, participation banks also bear risks of no - or missing repayment in credits. Moreover, the no repayment risk in credits grows with sector-specific risk if there are sectorspecific concentrations. It is also recommended to take it into consideration that the increase in non-cash credits is likely to be devastating if those credits are integrated into the sector-specific risks. 


\section{e) Liquidity Risk}

Liquidity risk is, as for all banks, extremely dangerous for participation banks so that it is widely thought that participation banks not borrowing in the interbank market are more likely to face this risk. Almost none of the financial institutions have reserved money to fund sudden giant cash outflows. An absolute and a considerable liquidity risk occur when there is maturity differences between funds collected and credits distributed. It has been already known that the average maturity of deposits is lower than credit maturities in Turkey. It might be worth to mention that the encompassment of participation banks by deposit guarantee system that is built to avoid abrupt withdrawals through established recent fund may decrease the liquidity risk for those banks. Recently, according to the knowledge gained through sectorspecific meetings, the infrastructure for funding mechanisms, such as a central bank, has been attempted to be developed for participation banks to create funds. Such a system is likely to decrease the liquidity risk for those banks.

\section{f) Operational Risk}

Most of the operational risks are also the case for participation banks. Apart from them, participation banks will have continued to bear operational risks with their potentials related to fast growth and to branching. Although the strategies such as the choice of branch locations, and the determination process of priorities, seem to be successful, the alternative costs associated with those might be greater. Participation banks are, on the one hand, expected to benefit from the experiences of deposit banks. On the other hand, they are supposed to create academic and applied working groups to determine alternative strategies. Especially, they are anticipated to produce boards that are prone to undertake technique-based studies, from the perspective of accounting - and law order, for instrumental diversification.

\section{Evaluation of Sectoral Quantitative Data Total Funds Collected, 2007-2015}

As of the end of 2015, total funds collected by participation banks reached to approximately 74 billion Turkish Liras, after an increase of $400 \%$ compared to the end of 2007. Figures of participation banks and deposit banks are shown below which facilitates to make a relative analysis between them. The increase rate for deposit banks is $241 \%$ in the same period. When figures are compared as of the end of 2007 and 2015, it is seen that participation banks have almost two times bigger percentage of increase than deposit banks on the percentage basis in terms of rate of increase.

Table 1: Fund Distribution of Participation and Deposit Banks, 2007-2015 (Million TL)

\begin{tabular}{|c|c|c|c|c|c|c|c|c|c|c|}
\hline & ڤิ̀ & ڤ్ & ثิ & ํํํ & $\overline{\text { กี }}$ & ลี & ڤึ & ¿্̃. & 높 & 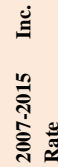 \\
\hline $\begin{array}{l}\text { Deposit } \\
\text { Banks }\end{array}$ & $\begin{array}{l}343 . \\
031\end{array}$ & $\begin{array}{l}435 . \\
554\end{array}$ & $\begin{array}{l}487 . \\
909\end{array}$ & $\begin{array}{l}583 . \\
947\end{array}$ & $\begin{array}{l}656 . \\
276\end{array}$ & $\begin{array}{l}724 . \\
296\end{array}$ & $\begin{array}{l}884 . \\
457\end{array}$ & $\begin{array}{l}987 . \\
433\end{array}$ & $\begin{array}{l}1 . \\
170 . \\
689\end{array}$ & $\begin{array}{l}241 \\
\%\end{array}$ \\
\hline $\begin{array}{l}\text { Participati } \\
\text { on Banks }\end{array}$ & $\begin{array}{l}14 . \\
834\end{array}$ & $\begin{array}{l}19 . \\
045\end{array}$ & $\begin{array}{l}26 . \\
711\end{array}$ & $\begin{array}{l}33 . \\
089\end{array}$ & $\begin{array}{l}39 . \\
220\end{array}$ & $\begin{array}{l}47 . \\
921\end{array}$ & $\begin{array}{l}61 . \\
313\end{array}$ & $\begin{array}{l}65 . \\
230\end{array}$ & $\begin{array}{l}74 . \\
176\end{array}$ & $\begin{array}{l}400 \\
\%\end{array}$ \\
\hline $\begin{array}{l}\text { Deposit+P } \\
\text { articipatio } \\
\text { n B. }\end{array}$ & $\begin{array}{l}357 . \\
865\end{array}$ & $\begin{array}{l}454 . \\
599\end{array}$ & $\begin{array}{l}514 . \\
620\end{array}$ & $\begin{array}{l}617 . \\
036\end{array}$ & $\begin{array}{l}695 . \\
496\end{array}$ & $\begin{array}{l}772 . \\
217\end{array}$ & $\begin{array}{l}945 . \\
770\end{array}$ & $\begin{array}{l}1 . \\
052 . \\
663\end{array}$ & $\begin{array}{l}1 . \\
244 . \\
865\end{array}$ & \begin{tabular}{|l|}
248 \\
$\%$
\end{tabular} \\
\hline
\end{tabular}

Source: Composed from data provided by (PBAT: The Participation Banks Association of Turkey, 2007-15 Consolidated Company Reports).

Table 2: Funds Utilized-Participation Banks and Deposit Banks in Turkey 2007-2015 (Million TL)

\begin{tabular}{|c|c|c|c|c|c|c|c|}
\hline & 옹 & $\stackrel{m}{\stackrel{D}{*}}$ & 응 & ষ্ণ & 突 & 늘 & 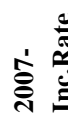 \\
\hline $\begin{array}{l}\text { Deposit } \\
\text { Banks Total } \\
\text { Loans }\end{array}$ & $\begin{array}{l}262 . \\
572\end{array}$ & $\begin{array}{l}939 . \\
772\end{array}$ & $258 \%$ & $\begin{array}{l}1.118 \\
.887\end{array}$ & $326 \%$ & $\begin{array}{l}1.339 \\
.149\end{array}$ & $410 \%$ \\
\hline $\begin{array}{l}\text { Participation } \\
\text { Banks Total } \\
\text { Loans }\end{array}$ & $\begin{array}{l}14 . \\
072\end{array}$ & $\begin{array}{l}62 . \\
029\end{array}$ & $341 \%$ & $\begin{array}{l}64 . \\
065\end{array}$ & $355 \%$ & $\begin{array}{l}72 . \\
038\end{array}$ & $412 \%$ \\
\hline
\end{tabular}

*Increase rate calculated based on 2007.

Source: Composed from data provided by (BAT: The Bank Association of Turkey, 2016) (http://ebulten.bddk.org.tr/ABMVC/\#)

Increase rate of loan-fund utilization from the end of 2007 to the end of 2013 of participation banks is higher than deposit bank's rate. They are $341 \%$ and $258 \%$ in that order. But difference reduced especially after one biggest participation bank is seized by insurance fund. They are $410 \%$ and $412 \%$ in that order.

\section{Growth of Total Assets}

When we look at the table of growth of assets, it is seen that participation banks provide the growth in the 2007-2015 period according to deposit banks. Participation banks increased their total assets by 394\% owing to deposit banks which increased their total assets by 189 . The table clearly shows that participation banks have increased theirs shares in the sector. While the share of participation banks was \%3,3 in 2007, the share reached to \%5,6 in the end of 2013. After 2013, 
there was a drop in the growth trend of the participation banks. As a reason for this, the political problems faced by the owners of the largest participation banks are shown. But since 2007, the market share increase seems to be a trend.

Table 3: The Shares of Participation Banks within the Sector

\begin{tabular}{|c|c|c|c|c|c|c|c|}
\hline & $\begin{array}{l}\text { (1.000. } \\
000)-\end{array}$ & Depo & it Banks & $\begin{array}{l}\text { Dev. } \\
\text { Banks }\end{array}$ & and Inv. & $\begin{array}{l}\text { Partic } \\
\text { Banks }\end{array}$ & pation \\
\hline $\begin{array}{l}\text { e } \\
\text { A }\end{array}$ & Sector & $\begin{array}{l}\text { Total } \\
\text { Assets }\end{array}$ & $\begin{array}{l}\text { Ratio in } \\
\text { the Sector }\end{array}$ & $\begin{array}{l}\text { Total } \\
\text { Assets }\end{array}$ & $\begin{array}{l}\text { Ratio in } \\
\text { the Sector }\end{array}$ & $\begin{array}{l}\text { Total } \\
\text { Assets }\end{array}$ & $\begin{array}{l}\text { Ratio in } \\
\text { the Sector }\end{array}$ \\
\hline $\begin{array}{l}20 \\
15\end{array}$ & $\begin{array}{l}2.355 \\
561\end{array}$ & $\begin{array}{l}2.129 \\
.397\end{array}$ & $90,40 \%$ & $\begin{array}{l}106 . \\
597\end{array}$ & $4,53 \%$ & $\begin{array}{l}119 . \\
567\end{array}$ & $5,08 \%$ \\
\hline $\begin{array}{l}20 \\
14\end{array}$ & $\begin{array}{l}1.992 . \\
538\end{array}$ & $\begin{array}{l}1.803 \\
.780\end{array}$ & $90,53 \%$ & $\begin{array}{l}84 . \\
529\end{array}$ & $4,24 \%$ & $\begin{array}{l}104 . \\
229\end{array}$ & $5,23 \%$ \\
\hline $\begin{array}{l}20 \\
13\end{array}$ & $\begin{array}{l}1.731 . \\
392\end{array}$ & $\begin{array}{l}1.565 \\
.258\end{array}$ & $90,40 \%$ & $\begin{array}{l}70 . \\
112\end{array}$ & $4,05 \%$ & $\begin{array}{l}96 . \\
022\end{array}$ & $5,55 \%$ \\
\hline $\begin{array}{l}20 \\
12\end{array}$ & $\begin{array}{l}1.368 \\
387\end{array}$ & $\begin{array}{l}1.245 \\
.416\end{array}$ & $91,01 \%$ & $\begin{array}{l}52 . \\
726\end{array}$ & $3,85 \%$ & $\begin{array}{l}70 . \\
245\end{array}$ & $5,13 \%$ \\
\hline $\begin{array}{l}20 \\
11\end{array}$ & $\begin{array}{l}1.217 . \\
695\end{array}$ & $\begin{array}{l}1.119 \\
.911\end{array}$ & $91,97 \%$ & $\begin{array}{l}41 . \\
636\end{array}$ & $3,42 \%$ & $\begin{array}{l}56 . \\
148\end{array}$ & $4,61 \%$ \\
\hline $\begin{array}{l}20 \\
10\end{array}$ & $\begin{array}{l}1.006 . \\
668\end{array}$ & $\begin{array}{l}932 . \\
371\end{array}$ & $92,62 \%$ & $\begin{array}{l}30 . \\
958\end{array}$ & $3,08 \%$ & $\begin{array}{l}43 . \\
339\end{array}$ & $4,31 \%$ \\
\hline $\begin{array}{l}20 \\
09\end{array}$ & $\begin{array}{l}834 . \\
014\end{array}$ & $\begin{array}{l}773 . \\
357\end{array}$ & $92,73 \%$ & $\begin{array}{l}27 . \\
029\end{array}$ & $3,24 \%$ & $\begin{array}{l}33 . \\
628\end{array}$ & $4,03 \%$ \\
\hline $\begin{array}{l}20 \\
08\end{array}$ & $\begin{array}{l}732 . \\
536\end{array}$ & $\begin{array}{l}683 . \\
823\end{array}$ & $93,35 \%$ & $\begin{array}{l}22 . \\
943\end{array}$ & $3,13 \%$ & $\begin{array}{l}25 . \\
770\end{array}$ & 3,52\% \\
\hline $\begin{array}{l}20 \\
07\end{array}$ & $\begin{array}{l}581 . \\
605\end{array}$ & $\begin{array}{l}543 . \\
272\end{array}$ & $93,41 \%$ & $\begin{array}{l}18 . \\
888\end{array}$ & $3,25 \%$ & $\begin{array}{l}19 . \\
445\end{array}$ & $3,34 \%$ \\
\hline
\end{tabular}

Source: Composed from data provided by (BAT, The Bank Association of Turkey, 2011-2015) (BAT, The Bank Association of Turkey, 2012-15) (PBAT, The Participation Banks Association of Turkey, 2012-15).

\section{Share in the Sector}

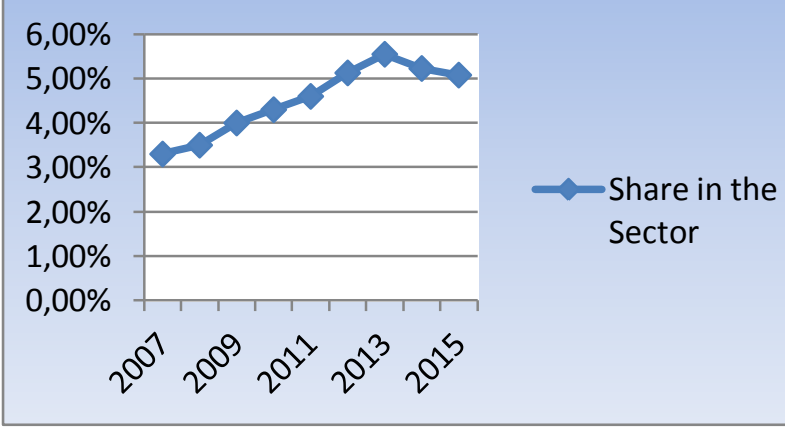

Figure 2. Share of Participation Banks in Turkish Banking Sector

\section{Conclusion}

"Participation Banks" formerly known as "Special Finance Houses" are companies collecting funds similar to deposit through private current accounts and accounts giving right to profit/loss participation, and utilizing funds through methods such as production support, leasing, document against payment, partnership of profit and loss. The establishment of these companies in Turkey has been allowed since 1984 .

The general risk assessment for participation banking is as follows:

- The difference in those systems is able to minimize the interest risk for participation banks into a great extent.

- $\quad$ Participation banks pay attention for not taking open or closed position that lead to exchange rate risk. However, exchange rate risk is a risk that is supposed to be seriously considered by all the financial institutions.

- Participation banks do not trade interest ratebased bonds and bills, but equities. The funds that are generated as basing upon the CMB regulations can be directed by managers that are authorized by participation banks. This risk would continue to be borne as long as the idle funds, apart from the ones that are already been established, have been used through security trade-off.

- As participation banks do not offer cash credits, they are pulled away from taking credit risks based upon fictive transactions. However, like others, participation banks also bear risks of no - or missing repayment in credits.

- Liquidity risk is, as for all banks, extremely dangerous for participation banks so that it is widely thought that participation banks not borrowing in the interbank market are more likely to face this risk.

- Most of the operational risks are also the case for participation banks. Apart from them, participation banks will have continued to bear operational risks with their potentials related to fast growth and to branching.

These companies which are subject to most limitations of general arrangements and loan limitations in the Turkish Banking Act differ from deposit banks at most in terms of that they don't undertake the risk of interest. These kinds of banks don't undertake the risk of interest which is one of the greatest risks which have to be managed in banking sector. We can talk about an asset-liability balance which is less sensitive to financial crisis. However not to undertake the risk of interest, in these kinds of banks, differently from deposit banks, eliminates the opportunity to obtain sudden and high institutional profit based on interest rate difference. 
However, growth of volume and branch number in the finance sector particularly in the last years is also extremely valid for these companies. Their share is relatively small today in total sector, but it grows in a steady way with their higher development rate than other banks. In 2001, participation banks had total asset amount of 2,4 billion TL which meant a share of $1,08 \%$ in the total assets of the sector. These amounts and shares were 7,3 billion TL and 2,33 \% in 2004, 13.730 billion TL and 2,75 \% in 2006, 25.769 billion TL and \% 3,50 in 2008, and 96.022 billion TL and 5,6 $\%$ as of the end of 2013. After 2013, there was a drop in the growth trend of the participation banks. As a reason for this, political and legal problems faced by the owners of the largest participation bank are indicated. But since 2007, the market share increase seems to be a trend.

It can be summarized as follows on the comparison of deposit and participation banks:

- Increase rate of loan-fund use from the end of 2007 to the end of 2013 of participation banks is higher than deposit banks' rate. They are $341 \%$ and $258 \%$ in that order. But, differences have reduced after 2013. They are $410 \%$ and $412 \%$ for that order.

- The rate of participation banks is slightly higher than deposit banks. In terms of average profit per bank, deposit banks intrinsically have very high figures compared to participation banks. However, the average number of branches, their scale and the history of deposit banks are above participation banks.

By the way, the participation banks also have some problems. For example, they need the Interbank system which provides urgent proper credits for the depository banks in the short run. But, this situation negatively affects the participation banks' performance. Because, they are sharing almost all of their funds for the creditors or investors who uses them for leasing, sales, trade, production, export and imports which constitutes the real sector in the economy.

For that reason, it is very important for participation banks forming the similar interbank organization which would increase their customers and operational transactions. For instance, the establishment of guaranty insurance system among the participation banks optimistically influenced their growth in the market.

\section{REFERENCES}

Abdul-Majid,M.A.(2008), "Islamic and Conventional Bank Performance: A Review of Literature", Working Paper in Islamic Economics and Finance No. 0819; Universiti Kebangsaan Malaysia, https://www.academia.edu/4410417/Islamic_a nd_Conventional_Bank_Performance_A_Revi ew_of_Literature

Ahmad, A., Humayoun, A. A., \& Hassan, U. u. (2010). An Analysis of Functions Performed by Islamic Bank: A Case of Pakistan. European Journal of Social Sciences, 17 (1), 7-12.

Aminuddin, I.(2010), “Application of Funds", http://www.islamicbankingway.com/2010/11/2 2-application-of-funds.html

BAT, The Bank Association of Turkey. (2008). Bankalarımız 2007. İstanbul: Türkiye Bankalar Birliği.

BAT, The Bank Association of Turkey. (2009). Bankalarımız 2008. İstanbul: Türkiye Bankalar Birliği.

BAT, The Bank Association of Turkey. (2010). Bankalarımız 2009. İstanbul: Türkiye Bankalar Birliği.

BAT, The Bank Association of Turkey. (2011). Bankalarımız 2010. İstanbul: Türkiye Bankalar Birliği.

BAT, The Bank Association of Turkey. (2012). Bankalarımız 2011. İstanbul: Türkiye Bankalar Birliği.

BAT, The Bank Association of Turkey. (2013). Bankalarımız 2012. İstanbul: Türkiye Bankalar Birliği.

BAT, The Bank Association of Turkey. (2014). Bankalarımız 2013. İstanbul: Türkiye Bankalar Birliği.

BAT, The Bank Association of Turkey. (2014). 2013 4.Quarter Information. İstanbul: Türkiye Bnk. Birliği.

Chong, B. S., \& Liu, M. H. (2009). Islamic banking: Interest-free or interest-based? Pacific-Basin Finance Journal, 17, 125-144.

Moles, P., \& Tery, N. (1999). The Handbook of International Financial Terms. United Kingdom: Oxford University Press. 
The Participation Banks Association of Turkey-FAQ. (2010, 12 28). Retrieved 2010, from The Participation Banks Association of Turkey: http://www.tkbb.org.tr/index.php?option=com_ content\&task=blogcategory\&id $=46 \&$ Itemid $=8$ 3 